\title{
Current outcomes and treatment of tetralogy of Fallot
}

\section{[version 1; peer review: 2 approved]}

\author{
Jelle P.G. van der Ven (D1)-3, Eva van den Bosch1,2, Ad J.C.C. Bogers ${ }^{3}$, \\ Willem A. Helbing 1,4
}

${ }^{1}$ Department of Pediatrics, Division of Pediatric Cardiology, Erasmus MC-Sophia Children's Hospital, Rotterdam, The Netherlands
${ }^{2}$ Netherlands Heart Institute, Utrecht, The Netherlands
3Department of Cardiothoracic Surgery, Erasmus MC, Rotterdam, The Netherlands
${ }^{4}$ Department of Pediatrics, Division of Pediatric Cardiology, Radboud UMC - Amalia Children's Hospital, Nijmegen, The Netherlands

V1 First published: 29 Aug 2019, 8(F1000 Faculty Rev):1530

https://doi.org/10.12688/f1000research.17174.1

Latest published: 29 Aug 2019, 8(F1000 Faculty Rev):1530

https://doi.org/10.12688/f1000research.17174.1

\section{Abstract}

Tetralogy of Fallot (ToF) is the most common type of cyanotic congenital heart disease. Since the first surgical repair in 1954, treatment has continuously improved. The treatment strategies currently used in the treatment of ToF result in excellent long-term survival (30 year survival ranges from $68.5 \%$ to $90.5 \%$ ). However, residual problems such as right ventricular outflow tract obstruction, pulmonary regurgitation, and (ventricular) arrhythmia are common and often require re-interventions. Right ventricular dysfunction can be seen following longstanding pulmonary regurgitation and/or stenosis. Performing pulmonary valve replacement or relief of pulmonary stenosis before irreversible right ventricular dysfunction occurs is important, but determining the optimal timing of pulmonary valve replacement is challenging for several reasons. The biological mechanisms underlying dysfunction of the right ventricle as seen in longstanding pulmonary regurgitation are poorly understood. Different methods of assessing the right ventricle are used to predict impending dysfunction. The atrioventricular, ventriculo-arterial and interventricular interactions of the right ventricle play an important role in right ventricle performance, but are not fully elucidated. In this review we present a brief overview of the history of ToF, describe the treatment strategies currently used, and outline the long-term survival, residual lesions, and re-interventions following repair. We discuss important remaining challenges and present the current state of the art regarding these challenges.

Keywords

Tetralogy, Fallot, Congenital Heart Disease, Survival, Outcomes

\section{Open Peer Review}

Approval Status

1

2

version 1

29 Aug 2019

Faculty Reviews are review articles written by the prestigious Members of Faculty Opinions. The articles are commissioned and peer reviewed before publication to ensure that the final, published version is comprehensive and accessible. The reviewers who approved the final version are listed with their names and affiliations.

1. Gianfranco Butera, Evelina London Children's Hospital, Guy's and St Thomas' NHS Foundation Trust, London, UK

2. Luc Mertens, University of Toronto, Toronto, Canada

Any comments on the article can be found at the end of the article. 
Corresponding author: Willem A. Helbing (w.a.helbing@erasmusmc.nl)

Author roles: van der Ven JPG: Investigation, Writing - Original Draft Preparation; van den Bosch E: Investigation, Writing - Review \& Editing; Bogers AJCC: Supervision, Writing - Review \& Editing; Helbing WA: Supervision, Writing - Review \& Editing

Competing interests: No competing interests were disclosed.

Grant information: J.P.G. van der Ven and E. van den Bosch were supported by a research grant from the Dutch Heart Foundation (grant 2013 T091 to W.A. Helbing and V.M. Christoffels).

The funders had no role in study design, data collection and analysis, decision to publish, or preparation of the manuscript.

Copyright: @ 2019 van der Ven JPG et al. This is an open access article distributed under the terms of the Creative Commons Attribution License, which permits unrestricted use, distribution, and reproduction in any medium, provided the original work is properly cited.

How to cite this article: van der Ven JPG, van den Bosch E, Bogers AJCC and Helbing WA. Current outcomes and treatment of tetralogy of Fallot [version 1; peer review: 2 approved] F1000Research 2019, 8(F1000 Faculty Rev):1530

https://doi.org/10.12688/f1000research.17174.1

First published: 29 Aug 2019, 8(F1000 Faculty Rev):1530 https://doi.org/10.12688/f1000research.17174.1 


\section{Introduction}

Tetralogy of Fallot (ToF), the most common type of cyanotic congenital heart disease (CHD), has an incidence of 0.34 per 1000 live births ${ }^{1}$. The classic tetrad (Figure 1) was first described in 1673 by bishop and anatomist Nicolas Steno, but the anatomy was more extensively described by the French physician Étienne-Louis Fallot in $1888^{2,3}$. Patients with ToF have varying degrees of cyanosis depending on the severity of right ventricular outflow tract (RVOT) stenosis and pulmonary artery (PA) anatomy. The anatomic abnormalities seen in ToF

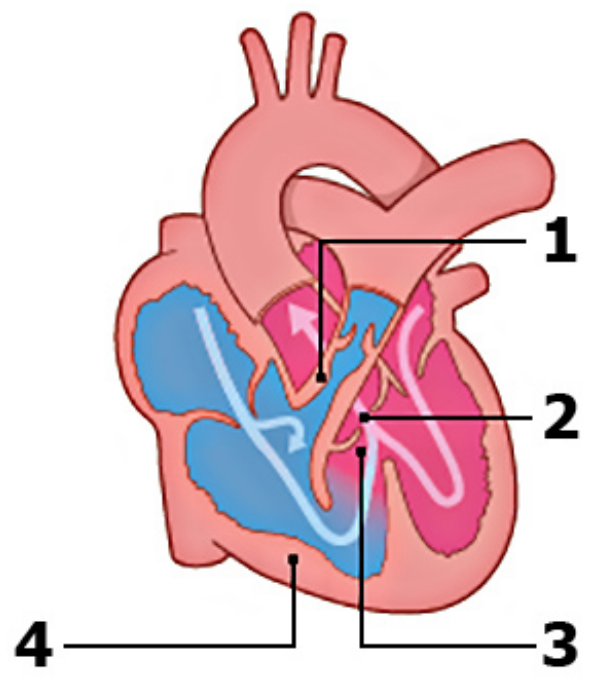

Figure 1. Schematic overview of the defects seen in tetralogy of Fallot. (1) Pulmonary stenosis. (2) Overriding aorta. (3) Malalignment ventricular septal defect. (4) Right ventricular hypertrophy. Modified from Englert et al. ${ }^{4}$ with permission from the publisher. vary from milder to more severe phenotypes, such as ToF with pulmonary atresia and Fallot-type double outlet right ventricle $(\mathrm{RV})$. These more severe forms may require different management and treatment strategies. This review focuses on the "classic" ToF, with right ventricular outflow (pulmonary) stenosis, rather than atresia, and excluding double outlet right ventricle.

\section{Surgical approaches to repair}

Surgical repair of ToF was first described in 1955 by Lillehei et al. ${ }^{5}$. The right ventricular outflow tract obstruction (RVOTO) was approached by a ventriculotomy into the right ventricular anterior wall and relief included inserting a transannular patch (TAP) if required (Figure 2, left). Aggressive RVOTO relief was advocated as initial results had demonstrated that residual RVOTO was predictive of early mortality ${ }^{6}$. This approach resulted in relatively good long-term survival ${ }^{7}$. However, residual lesions after repair were common and follow-up studies of these first operations showed that these residual lesions resulted in late morbidity and mortality ${ }^{8-11}$. Pulmonary regurgitation (PR) was reported in the majority of patients, more commonly in those with TAPs ${ }^{12}$. PR initially was thought to be a relatively benign hemodynamic residual lesion but subsequently was found to be predictive of decreased exercise performance and progressive RV dilation. RV dilation, in turn, was associated with ventricular arrhythmia and biventricular dysfunction ${ }^{13-15}$. Furthermore, patients were noted to be at higher risk of sudden cardiac death $8,9,11,16,17$.

Different surgical techniques were developed minimizing the extent of the ventriculotomy and trying to preserve competence of the pulmonary valve without causing significant residual RVOTO. Via a transatrial or transatrial-transpulmonary approach, the need for a ventriculotomy can be reduced (Figure 2, right). The transatrial or transatrial-transpulmonary approach
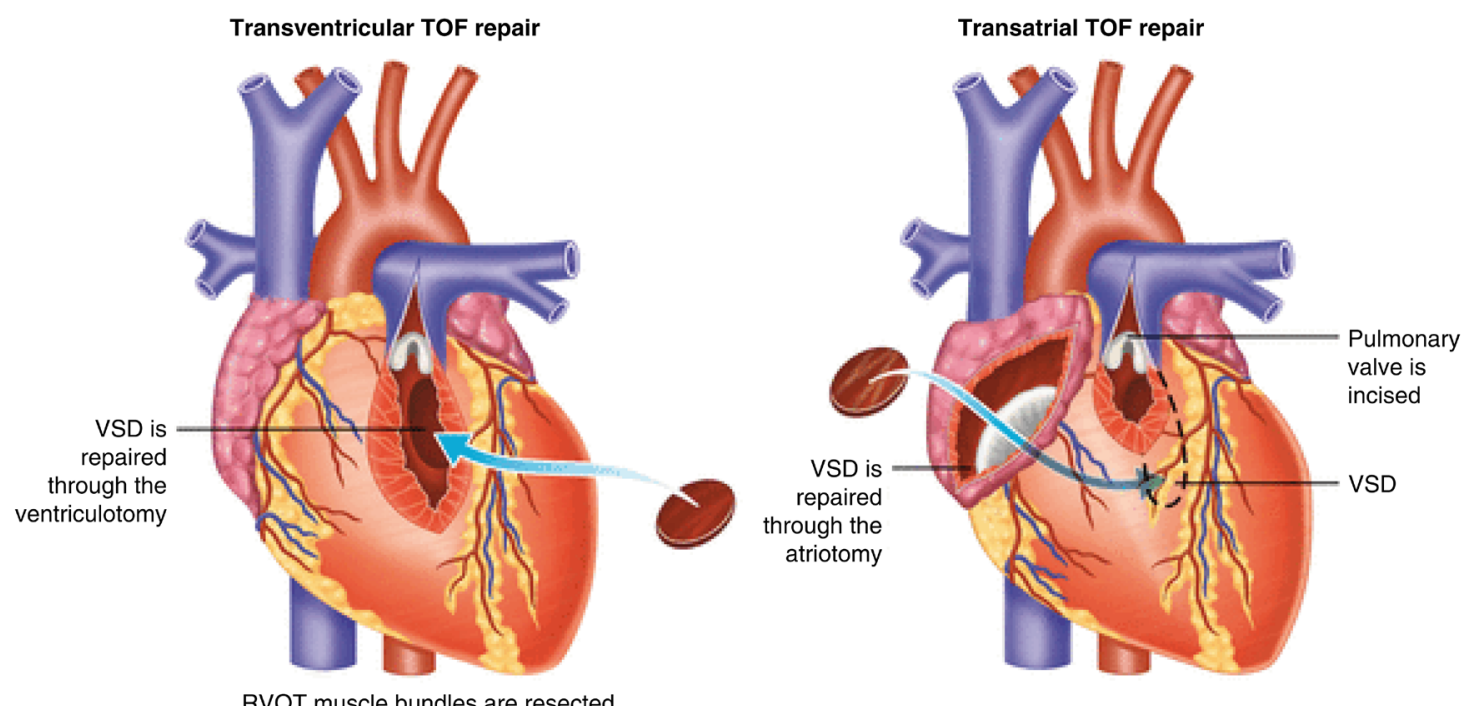

Figure 2. Transventricular (left) and transatrial-transpulmonary (right) approach to tetralogy of Fallot (ToF) repair. VSD, ventricular septal defect. Adapted from Bushman ${ }^{18}$ with permission from the publisher. 
is currently employed in most centers, and the long-term results are excellent ${ }^{12,19-22}$. In patients with a small pulmonary valve annulus, a TAP is still necessary for adequate RVOTO relief. Other techniques to preserve or replace pulmonary valve competence include pulmonary valvuloplasty with patching limited to the infundibulum ${ }^{23,24}$, implantation of a monocusp valve $^{25,26}$, a valved RV-to-PA conduit ${ }^{27,28}$, or a homograft valve $^{27}$. A survival benefit of these valve-sparing or valve-replacing techniques has not yet been demonstrated ${ }^{29-32}$.

\section{Variations in current treatment strategies}

In general, it is thought that earlier primary repair of ToF can limit prolonged exposure to RV pressure loading and reduced oxygen saturations, preserving cardiovascular ${ }^{33}$ and brain $^{34}$ function. However, there is no consensus on the definition of "early" versus later repair. Neonatal repair (that is, repair before 1 month of age) is feasible with acceptable results but is not widely used and this is because of better short-term outcomes of non-neonatal repair ${ }^{35}$. Neonatal repair more often requires TAP compared with repair beyond the neonatal period, resulting in worse event-free survival ${ }^{35}$. In the majority of patients, primary repair can be postponed to 3 to 6 months of age with excellent outcomes ${ }^{36,37}$.

Symptomatic ToF patients may require an intervention in the neonatal period. Different strategies can be used if primary repair is judged not to be the best option. Historically, a systemic-to-pulmonary shunt-typically a modified BlalockTaussig (mBT) shunt-has been used to increase pulmonary flow, reduce hypoxemia, and allow time for PA growth. This allows repair to be performed at an older age and has the potential advantage of using no, or less extensive, TAP. However, palliative shunt procedures are associated with a $3 \%$ to $5 \%$ early mortality rate ${ }^{38,39}$. The superiority of a staged approach versus primary neonatal repair has not been demonstrated ${ }^{40,41}$.

Stenting of the ductus arteriosus (DA) is another strategy to warrant pulmonary blood flow after birth by inducing a systemicto-pulmonary shunt. However, in cyanotic CHD, the anatomy of the DA might be complex and unsuited for stenting ${ }^{42}$. Procedural success is estimated to be $83 \%{ }^{43}$. Recently published multicenter studies compared outcomes following DA stenting and mBT shunting using propensity score-adjusted models ${ }^{43,44}$. Clinical status, assessed by saturation, hemoglobin levels, and PA size, was more favorable following DA stenting compared with $\mathrm{mBT}$ shunting ${ }^{43,44}$. Bentham et al. found better survival (hazard ratio $0.25,95 \%$ confidence interval (CI) 0.07-0.85) for DA stent compared with $\mathrm{mBT}^{43}$, whereas Glatz et al. found no difference in survival (hazard ratio $0.64,95 \%$ CI $0.28-1.47)^{44}$. A trend toward higher re-intervention rate in the DA stent group was observed in both studies ${ }^{43,44}$. DA stenting appears to be a feasible strategy for selected cases.

Alternatively, palliative balloon dilation of the pulmonary annulus can be used to increase oxygen saturation and promote growth of the pulmonary vasculature and as bridge to later complete repair in selected patients ${ }^{45,46}$. Whether this strategy ultimately reduces TAP use or improves long-term outcomes remains controversial ${ }^{45,46}$.
Similarly, RVOT stenting can be used as a palliative strategy or bridge to repair in neonatal life ${ }^{47,48}$. Experience with this strategy is still relatively limited but it has been demonstrated to be a relatively safe procedure promoting growth of the pulmonary arteries as a bridge to repair ${ }^{48-50}$. Quandt et al. compared medium-term outcomes of RVOT stent with systemic-topulmonary shunt and found no difference in survival between strategies $^{49}$. Intensive care and hospital stay duration and perioperative complications were more favorable for the RVOT stenting group but the re-intervention rate was higher for this group $^{49}$. The most common re-interventions in this group were re-stenting and re-ballooning. (Re)shunt surgery or early complete repair was less common in this group compared with patients who underwent primary $\mathrm{mBT}$. Comparisons between neonatal repair and RVOT stenting have shown comparable short-term and long-term outcomes ${ }^{51,52}$. During 10 years of follow-up, Wilder et al. demonstrated a similar increased rate of catheter-based re-interventions in the RVOT stent group compared with neonatal repair $^{52}$. More studies are needed to determine the best strategy for the patient group requiring early intervention. Management strategies likely need to be individualized for optimal outcome.

\section{Overall survival}

Overall survival following ToF repair has significantly improved in recent eras. Figure 3 outlines survival in several large studies published within the last two decades, and follow-up was up to 40 years for older cohorts ${ }^{12,53-65}$. Early mortality has significantly decreased in more recent eras. European and American congenital cardiothoracic surgery registries have reported a peri-operative mortality below $3 \%$ in recent years ${ }^{66-68}$. Peri-operative outcomes are determined largely by the severity of the ToF described by, for example, the pre-operative size of the pulmonary valve and pulmonary arteries, RV-PA pressure gradient, and oxygen saturation ${ }^{61,69-71}$. Patients with repair including TAP have higher peri-operative mortality ${ }^{66}$. As most centers consider a TAP only when the pulmonary annulus $\mathrm{z}$-score is lower than -2 or -3 , this in part reflects more severe $\mathrm{ToF}^{21,72}$. Furthermore, co-morbidities, such as coronary abnormalities, prematurity, small body size-associated lesions, and genetic abnormalities, have been associated with increased peri-operative mortality ${ }^{61,69-71,73}$.

Mortality rates at medium-term follow-up have not changed much across the different surgical eras (Figure 3) ${ }^{65}$. Survival at 30 years ranges from $68.5 \%$ to $90.5 \% \%^{54,57,58,62-65}$. Long-term (20 to 30 years) survival from large cohorts of patients operated on with more recent surgical modifications of ToF repair (for example, valve-sparing and valve-replacing techniques) is still lacking. Important factors determining long-term outcome are residual RVOTO and severity of $\mathrm{PR}^{54}$.

Survival into adulthood is currently expected following ToF repair, leading to a growing population of adults with corrected ToF who require lifelong specialized medical care ch-77. $^{74}$. Re-interventions are common in these patients. Cuypers et al. found that $44 \%$ of patients underwent at least one surgical or catheter re-intervention after 35 years of follow-up ${ }^{63}$. D'Udekem et al. found that $24 \pm 5 \%$ of patients underwent 


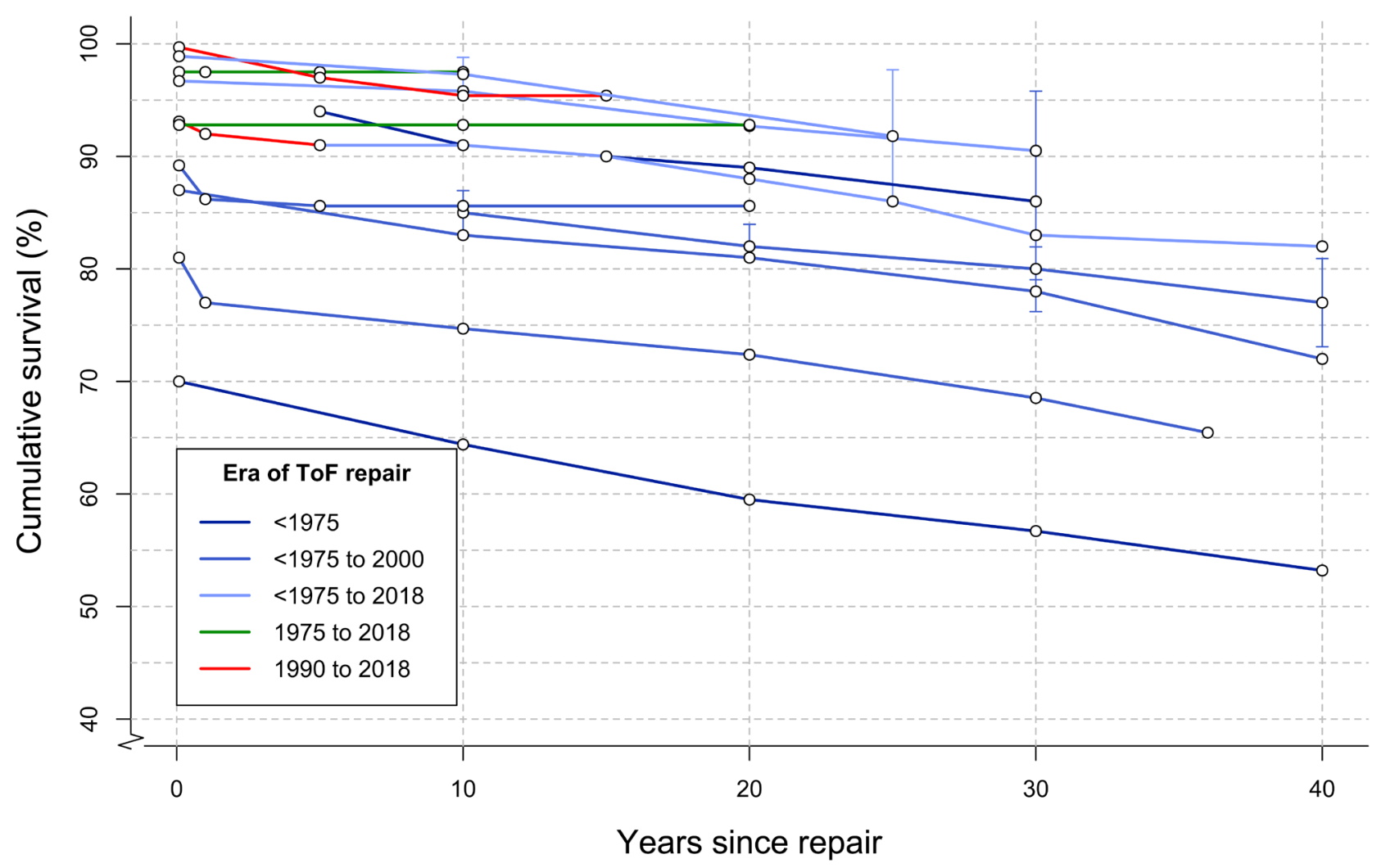

Figure 3. Survival following tetralogy of Fallot (ToF) repair. Each colored line represents a single study, and dots represent Kaplan-Meier survival estimates at different time points ${ }^{12,53-65}$. Ninety-five percent confidence intervals, where published, are shown in vertical lines. Lines are colored according to surgical era.

re-operation after 30 years of follow-up ${ }^{64}$. Following transatrial transpulmonary repair, lower rates of re-interventions have been reported. Luijten et al. ${ }^{12}$ found a $80 \%$ freedom of reintervention and death after 10 years and D'Udekem et al. ${ }^{64}$ found $75 \%$ freedom of re-operation after 25 years. A small case-control study found a lower pulmonary valve replacement (PVR) rate following transatrial repair compared with transventricular repair. The use of a TAP is associated with a higher

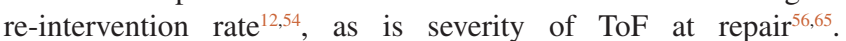
Specific indications for re-interventions will be discussed later in this article.

\section{Residual problems and re-interventions}

\section{Residual right ventricle outflow tract obstruction}

Residual RVOTO is common following repair and results in residual or progressive concentric hypertrophy of the RV. Data obtained from the INDICATOR study suggest that RV hypertrophy, due to increased mass-to-volume ratio, is a more important long-term risk factor for ventricular tachycardia (VT) and death than severity of RV dilation (RV end-diastolic volume index $)^{78}$. Current guidelines provide clear indications for re-intervention for residual RVOTO (Table 1) (5-77 $^{75}$ Balloon valvuloplasty or PVR can be performed for valvular pulmonary stenosis (PS). PA branch stenosis can be safely relieved by balloon dilation, stenting, or PA reconstruction ${ }^{79}$. In several large studies, $1 \%$ to $7 \%$ of patients have undergone PA dilation or stenting at long-term follow-up (median of 5.8 to 36 years) ${ }^{61,63,64,80,81}$. Surgical relief of the RVOT and PA plasties were performed in $1 \%$ to $5 \%$ of patients at long-term follow-up $p^{61,63,80,81}$.

\section{Pulmonary regurgitation}

$\mathrm{PR}$ is very common at medium- to long-term follow-up. Five to ten years after repair, $40 \%$ to $85 \%$ of patients have moderate to severe $\mathrm{PR}^{53,73,82-84}$. PR induces $\mathrm{RV}$ volume overload of the RV with often progressive RV dilation, which may include the development of tricuspid regurgitation (TR) and RV dysfunction. It is often accompanied by prolongation of the QRS complex, and RV dyssynchrony could contribute to the progression of dysfunction ${ }^{85-87}$. There generally is a long period in a compensated state, during which RV function is maintained. In some patients, these compensatory mechanisms fail, leading to progressive RV dysfunction ${ }^{85,86}$. The mechanisms of $\mathrm{RV}$ adaptation and remodeling, as well as the molecular events contributing to the transition from a compensated to a decompensated state, are still poorly understood. Timely restoration of pulmonary valve competence is considered to halt the progressive adverse RV remodeling resulting in RV dysfunction seen in chronic PR. 
Table 1. Indications for pulmonary valve replacement in current guidelines.

\begin{tabular}{|c|c|c|c|}
\hline & $\begin{array}{l}\text { European Society of Cardiology } \\
(2010)^{75}\end{array}$ & $\begin{array}{l}\text { American College of Cardiology/American Heart } \\
\text { Association (2008) }{ }^{73}\end{array}$ & $\begin{array}{l}\text { Canadian Cardiovascular } \\
\text { Society }(2009)^{74}\end{array}$ \\
\hline Class I & $\begin{array}{l}\text { Symptomatic patients with severe PR } \\
\text { and/or } \\
\text { PS (RV systolic pressure }>60 \mathrm{~mm} \mathrm{Hg} \text {, } \\
\text { TR velocity }>3.5 \mathrm{~m} / \mathrm{s} \text { ) }\end{array}$ & $\begin{array}{l}\text { Severe PR } \\
\text { and } \\
\text { Symptoms or decreased exercise tolerance }\end{array}$ & \\
\hline Class Ila & $\begin{array}{l}\text { Severe PR or PS (or both) } \\
\text { and either: }\end{array}$ & $\begin{array}{l}\text { Severe PR } \\
\text { and either: }\end{array}$ & $\begin{array}{l}\text { Free PR } \\
\text { and either: }\end{array}$ \\
\hline RV size & & Moderate to severe RV enlargement & EDVi $170 \mathrm{~mL} / \mathrm{m}^{2}$ \\
\hline $\begin{array}{l}\text { Progression of } \\
\text { RV size }\end{array}$ & Progressive RV dilation & & Progressive RV dilation \\
\hline RV function & Progressive RV dysfunction & Moderate to severe RV dysfunction & $\begin{array}{l}\text { Moderate to severe RV } \\
\text { dysfunction }\end{array}$ \\
\hline TR & Progressive TR, at least moderate & Moderate to severe TR & Important TR \\
\hline PS & $\begin{array}{l}\text { PS RV systolic pressure greater than } \\
80 \mathrm{~mm} \mathrm{Hg} \text {, TR velocity } 4.3 \mathrm{~m} / \mathrm{s}\end{array}$ & $\begin{array}{l}\text { Peak instantaneous echocardiography gradient } \\
\text { greater than } 50 \mathrm{~mm} \mathrm{Hg} \\
\text { or } \\
\text { RV/LV pressure ratio greater than } 0.7 \\
\text { or } \\
\text { Residual RVOT obstruction (valvular or subvalvular) } \\
\text { with progressive and/or severe dilatation of the RV } \\
\text { with dysfunction }\end{array}$ & $\begin{array}{l}\text { RV pressure at least } 2 / 3 \\
\text { systemic pressure }\end{array}$ \\
\hline $\begin{array}{l}\text { Exercise } \\
\text { capacity }\end{array}$ & $\begin{array}{l}\text { Decrease in objective exercise } \\
\text { capacity }\end{array}$ & & $\begin{array}{l}\text { Symptoms such as } \\
\text { deteriorating exercise } \\
\text { performance }\end{array}$ \\
\hline Arrhythmia & $\begin{array}{l}\text { Sustained atrial or ventricular } \\
\text { arrhythmia }\end{array}$ & $\begin{array}{l}\text { Symptomatic or sustained atrial and/or ventricular } \\
\text { arrhythmias }\end{array}$ & $\begin{array}{l}\text { Atrial or ventricular } \\
\text { arrhythmia }\end{array}$ \\
\hline
\end{tabular}

EDVi, end-diastolic volume index; LV, left ventricle; PR, pulmonary regurgitation; PS, pulmonary stenosis; RV, right ventricle; RVOT, right ventricle outflow tract; TR, tricuspid regurgitation.

Thirty-five years after ToF repair, PVR will have been performed in about $40 \%$ of patients ${ }^{63,65,88}$. Staged repair and TAP are risk factors for late PVR ${ }^{12,54,63,80}$, whereas mild residual PS seems to reduce risk $^{89}$. As more patients with ToF survive into adulthood, PVRs are increasingly being performed ${ }^{90}$.

PVR is effective in decreasing RV volumes, reducing TR, decreasing QRS duration, increasing left ventricle (LV) ejection fraction (EF), and improving functional status ${ }^{91,92}$. It should be noted that no improvement in survival following PVR compared with medical management has been demonstrated to date ${ }^{93,94}$.

Homograft or bioprosthetic valves are currently the preferred valves for $\mathrm{PVR}^{95}$. The current 10-year re-PVR-free survival of ToF patients undergoing homograft PVR ranges from $74 \%$ to $89 \%{ }^{95,96}$.

Tissue-engineered valves with a non-synthetic and nonimmunogenic surface have the potential to provide lifelong valve replacement ${ }^{97}$. In situ tissue engineering techniques, in which a decellularized "starter scaffold" of polymers can be used to provide shape and structure to the valve, are of particular interest. This scaffold is infiltrated by endogenous cells to provide a regenerating functional valve. As the scaffold would be non-immunogenic, this could provide a relatively cheap "off the shelf" valve. Current studies evaluating tissue-engineered valves in animals and humans show promising early results ${ }^{98}$.

Several transcatheter PVR strategies have been developed and are increasingly used in a clinical (trial) setting ${ }^{99}$. However, clinical experience compared with (surgical) homograft PVR is limited ${ }^{99}$. Procedural success of transcatheter PVR is generally good $(>95 \%)^{100}$. The hazard rate for re-intervention following transcatheter PVR ranges from $0.4 \%$ to $5.9 \%$ per patient-year ${ }^{100}$. However, high rates of infective endocarditis during follow-up have been described ${ }^{101}$. Recent results from the MELODY Registry estimate the infective endocarditis risk to be $2.3 \%$ per patient-year ${ }^{102}$. In comparison, the infective endocarditis risk in surgical PVR has been estimated to be $0.3 \%$ per patient-year ${ }^{103}$. Transcatheter PVR has been shown to increase exercise capacity and quality of life 6 months after the procedure ${ }^{104,105}$. Direct comparisons with surgical PVR are still lacking. 


\section{Arrhythmia}

Ventricular tachycardia. VT is a common arrhythmia in the repaired ToF population. Cuypers et al. reported a 5\% cumulative incidence of sustained VT after a median of 35 years after ToF repair ${ }^{63}$ and these figures are similar to those of most reports $^{58,106}$. However, cumulative incidences of up to $15 \%$ have been reported in some adult populations ${ }^{107}$. Predictors of sustained VT include higher age, number of prior cardiac surgeries, presence of a TAP, LV diastolic dysfunction, and QRS width ${ }^{63,106-108}$. Most guidelines recommend implantable cardioverter defibrillators (ICDs) for patients who have had sustained VT or cardiac arrest $^{76,77}$. ICDs are also employed for primary prevention, although selecting high-risk patients who would benefit from ICD implantation remains challenging ${ }^{76,77}$. Pacemaker and ICD prevalences in adult ToF populations both range from $5 \%$ to $10 \%{ }^{63,107,109}$.

Electrophysiological studies can help to determine the underlying substrate, and radiofrequency ablation can be performed. Ablation of monomorphic VT substrates has excellent shortterm outcomes with recurrent VT in $18 \%$ of patients after a mean follow-up of 34 months $^{110}$. Another study found a similar recurrence rate (19\%) 10 years after ablation ${ }^{111}$.

Supraventricular tachycardia. The prevalence or cumulative incidence of supraventricular tachycardia (SVT) in adult patients ranges from $4 \%$ to $20 \%^{107-109,112}$. In the first 10 to 15 years following ToF repair, SVT is relatively uncommon but the incidence rises steadily after this period ${ }^{107}$. Intra-atrial reentrant tachycardia, typically involving the right atrium, is the most common type of SVT in patients with $\mathrm{ToF}^{107}$. Two large studies found that SVT was an independent predictor of death or $\mathrm{VT}^{78,108}$. Few studies have assessed the efficacy of ablation of atrial arrhythmias in corrected ToF, and long-term follow-up is lacking ${ }^{113-115}$.

\section{Aortopathy}

Dilation of the aorta is seen in $12 \%$ to $24 \%$ of adult patients with $\mathrm{ToF}^{116-118}$. In patients with aortic dilation, aortic root size seems to progressively increase over a period of years. Aortic dissection following ToF appears to be a rare complication ${ }^{119}$. A population-based study in Texas demonstrated no increased risk for thoracic aortic dissection for patients with ToF compared with the general population ${ }^{119}$. However, progressive aortic root dilation can lead to malcoaptation of the aortic valve and aortic regurgitation. Furthermore, the elasticity of the dilated aortic root was shown to be reduced in patients with ToF, possibly hampering circulatory function ${ }^{120}$. The importance of aortopathy in circulatory function and mortality remains incompletely understood.

\section{Knowledge gaps}

\section{Right ventricular adaptation and remodeling}

The mechanisms of RV adaptation and remodeling in response to chronic RV volume overload, resulting from PR, are poorly understood $^{121}$. In young pig models, chronic PR affects biventricular systolic function, RV myocardial contractility, and LV diastolic performance ${ }^{122}$. Histopathology of several animal models displays early hypertrophy of the chronically volumeloaded RV and, in a later stage, myocardial fibrosis ${ }^{121}$. The molecular responses to increased volume or pressure loading of the $\mathrm{RV}$ are different from those in the $\mathrm{LV}^{121,123-125}$. In a pig model of repaired ToF with induced PR, PS, and an RVOT scar, RV hypertrophy and dilation were found after 23 weeks. The myocardium was characterized by increased collagen deposition, leading to decreased impulse conduction velocity and dispersion ${ }^{126}$. Similar findings were found in the LV, despite preserved LV function at this stage. This demonstrates biventricular adverse effects are present early in the adverse remodeling process ${ }^{127}$.

Basic research into RV remodeling has focused mainly on the response to increased pressure loading rather than the predominantly volume-loaded $\mathrm{RV}$ as seen in $\mathrm{PR}^{124,125}$. Volume loading and pressure loading increase myocardial metabolic demand. This metabolic stress induces an increased amount of reactive oxygen species. Compensatory anti-oxidant production in the RV is impaired compared with the $\mathrm{LV}^{125}$. This might imply that the RV is more vulnerable to oxidative stress, as seen in abnormal loading conditions.

In volume-loaded RV mouse models, a clinical course similar to RV dysfunction with volume-loaded RV in humans is observed. RV function is maintained during a compensated phase, followed by RV dysfunction ${ }^{128}$. Gene expression patterns of the cardiomyocyte in the compensated state differ from those of healthy controls. Several molecular pathways, such as transforming growth factor beta (TGF- $\beta$ ) signaling, p53 signaling, and cytoskeleton-related pathways, are downregulated in the early compensated state but show late upregulation as the RV progressively remodels ${ }^{128}$. However, the exact cellular and molecular mechanisms of transition from a compensated to a decompensated state of the volume-loaded RV have not been fully elucidated ${ }^{125,129}$.

\section{Assessing the right ventricle in patients with tetralogy of}

Fallot

Our limited understanding of the pathophysiology of RV failure hampers our ability to adequately detect failure in the early stages in clinical practice. Imaging techniques are used to assess the RV and follow patients serially, aiming to detect early changes in biventricular size and performance. Cardiovascular magnetic resonance (CMR) imaging is routinely used to reliably quantify RV volumes and function, wall mass, and $\mathrm{PR}^{130}$. Adverse clinical events have been related to larger RV volumes, PR severity, biventricular EF, and mass-to-volume ratio $^{78,131,132}$. Increased RV volumes, most commonly end-diastolic volume index (EDVi), have been considered a sign of prolonged high PR burden and thus a predictor of RV dysfunction. However, exercise capacity can be preserved even in severely dilated ventricles, demonstrating that compensatory mechanisms can still be adequate to maintain performance of large $\mathrm{RV}^{133}$. In the INDICATOR cohort, increased RV wall mass-to-volume ratio, among other factors, was found to be an independent predictor of VT and all-cause mortality, whereas RV EDV and end-systolic volume were not predictive of the end-points ${ }^{78}$. 
RV hypertrophy could be a more sensitive marker of pending dysfunction than EDV, although this might be particularly true for patients with residual PS.

Regional myocardial performance and mechanical synchrony can be assessed by strain imaging studies. Global circumferential or longitudinal strain has been used to assess RV function. Under normal circumstances, the RV ejects mainly by longitudinal shortening while, with increased RV pressure loading, circumferential contraction is increased ${ }^{134}$. The predictive value of global longitudinal or circumferential strain in $\mathrm{ToF}$ is still uncertain: Orwat et al. found that RV global longitudinal strain assessed by CMR was a superior independent predictor for death, cardiac arrest, or VT compared with RV volumes ${ }^{135}$. RV global circumferential strain was not predictive of outcome in that study ${ }^{135}$. Diller et al. found a similar relation for LV global longitudinal strain assessed by echocardiography ${ }^{136}$.

Mechanical dyssynchrony has been demonstrated to relate to prolonged or fragmented (QRS complex containing additional spikes without bundle branch block) QRS complexes ${ }^{137}$. The contributions of this mechano-electrical interaction to RV function remain uncertain, as studies assessing mechanical dyssynchrony report conflicting results ${ }^{135,136,138-141}$. RV circumferential dyssynchrony was shown to negatively predict exercise capacity in one study ${ }^{140}$. This association has not been confirmed in other studies ${ }^{138,141}$. Cardiac resynchronization therapy is increasingly used in ToF. A recent study found that 12 out of 15 adult patients with ToF had an improved NYHA (New York Heart Association) class or LV function after 2.6 years (median) of cardiac resynchronization therapy ${ }^{142}$. Procedural success was high and adverse events were rare.

\section{Right ventricular interactions in tetralogy of Fallot}

Atrio-ventricular interactions. Diastolic function after $\mathrm{ToF}$ repair is a determinant of the amount of PR. In some patients, end-diastolic forward flow (EDFF) in the main PA during right atrial contraction can be observed ${ }^{143}$. This is considered a sign of "restrictive RV physiology" as the non-compliant RV acts as a conduit during atrial contraction as RV diastolic pressure exceeds PA diastolic pressure ${ }^{144,145}$. Restrictive physiology could limit the amount of PR as elevated diastolic RV pressure reduces the amount of PR. A recent study found no relationship between the presence of EDFF and other markers of diastolic dysfunction (that is, RV hypertrophy, atrial dilatation, reduced stroke volume, or reduced PR) ${ }^{146}$. Different mechanisms, such as pulmonary arterial capacitance and atrial function ${ }^{147}$, may play significant roles in the occurrence of EDFF. Luijnenburg et al. found that bi-atrial function, but not diastolic ventricular function, differed between patients with EDFF and those without $\mathrm{it}^{147}$. In that study, abnormal atrial function was related to worse exercise capacity and higher $\mathrm{N}$-terminal pro brain natriuretic peptide (NT-proBNP). Kutty et al. found that right atrial longitudinal strain predicted RV performance but not exercise capacity ${ }^{148}$.

The effect of EDFF on circulatory function is controversial. Studies found conflicting results regarding the relationship between EDFF and the amount of $\mathrm{PR}^{143,144,146}$, exercise capacity $^{144-147}$, and EDV ${ }^{144-147}$. The presence of EDFF might have a different etiology and clinical importance early versus late after repair or in severely dilated versus non-dilated ventricles.

Ventriculo-arterial interactions. Adequate atrio-ventricular coupling and ventriculo-arterial (VA) coupling are required for an energetically efficient transfer of blood through the right heart. VA coupling has not been studied extensively in ToF. Latus et al. assessed VA coupling as the relationship between pulmonary arterial elastance and ventricular endsystolic elastance in adult patients with ToF by using CMR and catheter-derived measurements both in resting conditions and during dobutamine stress ${ }^{149}$. VA coupling was impaired during resting conditions. EF and load-independent parameters of RV contractility increased during dobutamine stress. Pulmonary arterial elastance increased accordingly and the impaired VA coupling that resulted during dobutamine stress was similar to that under resting conditions.

Interventricular interactions. Interactions between the RV and LV have been extensively described. The LV and RV have common myocardial fibers, the interventricular septum, the anatomic space confined by the pericardium, and a common neurohumoral system ${ }^{150}$. Not unexpectedly, the effects of chronic PR are not limited to the RV, although the mechanisms of this ventriculo-ventriculo interaction in chronic PR remain poorly understood. A linear correlation between LV and RV EF has been described ${ }^{150,151}$. Severe RV dilation causes abnormal diastolic septal positioning, influencing LV filling ${ }^{152}$. The role of the LV in outcomes in ToF is increasingly appreciated, as LV function has been associated with increased mortality and increased risk of $\mathrm{VT}^{136,153}$. In the INDICATOR registry, LV EF was one of three independent predictors of mortality and $\mathrm{VT}^{154}$. Geva et al. found that LV EF, independent of RV parameters, predicted poor functional status ${ }^{151}$. Remarkably, parameters of LV function are not considered in current guidelines for the timing of PVR (Table 1).

\section{Drug therapy for right ventricular failure}

Pharmacotherapy is important in the treatment of LV failure and improves outcomes. However, the effects of the use of heart failure medication for RV failure have been disappointing ${ }^{155-157}$. In patients after ToF repair, RAAS (renin-angiotensinaldosterone system) inhibitors do not appear to influence RV $\mathrm{EF}$ or exercise capacity ${ }^{158}$. In a randomized controlled trial of 33 patients with ToF, beta blockers showed no beneficial effects after 6 months of treatment and an increase in NT-proBNP was noted ${ }^{159}$. Increasing our understanding of the pathophysiology of RV failure might elucidate new targets for medical treatment unique to the RV.

\section{Current guidelines on the timing of pulmonary valve replacement}

Restoring pulmonary valve function before irreversible RV dysfunction occurs could be important to prevent RV failure. However, the durability of currently used pulmonary prosthetic valves is limited. Therefore, the timing of PVR always is a 
compromise: It should be timed early enough to prevent irreversible adverse remodeling but late enough to limit the number of re-interventions. Because of the difficulties in assessing RV function, predicting decline in RV function is difficult, and the optimal timing of PVR is controversial. Guidelines by the European Society of Cardiology, the Canadian Cardiovascular Society (CCS), and the American College of Cardiology/ American Heart Association provide some recommendations on indications for performing $\mathrm{PVR}^{75-77}$. These indications are summarized in Table 1.

Indications differ between guidelines and have several limitations. Most guidelines do not provide specific cutoff points since these are statistical constructs that do not work for individual patients. The 2009 CCS guideline provides an absolute cutoff value for EDVi but does not take into account the considerable differences in normal (indexed) RV volumes between genders and age ${ }^{160}$. End-systolic volume index and RV mass-to-volume ratio have been proposed as superior predictors compared with $\mathrm{EDV}^{78,161}$. Progressive RV dilation is considered an indication for PVR, but there is no consensus on what too much progression is ${ }^{162-165}$. Longitudinal changes in $\mathrm{RV}$ size and function following ToF repair have been reported in several studies $^{166-173}$. RV volumes increase non-linearly and seem to stabilize in adolescence. These factors need to be taken into account when assessing progressive RV dilation.

Furthermore, the recommendations in current guidelines are often based on long-term outcomes of studies in patients who have been operated at a much older age than has been the practice in the past 20 years. This warrants caution when extrapolating these results to current adolescent or younger patients.

Careful interpretation of current guidelines seems to be justified. Individual patient parameters and views should always be taken into consideration. In clinical practice, an approach using information from different sources, including history, physical examination, electrocardiogram, imaging techniques, exercise testing, and blood biomarkers, may be most useful ${ }^{174}$.

\section{Conclusions}

ToF can be repaired with low short-term and long-term mortality. This has caused a demographic shift such that many patients survive well into adulthood. Long-term follow-up of older cohorts has shown the detrimental effects of PR in the long-term. However, residual lesions cause significant morbidity. Surgical modifications to preserve pulmonary valve function, such as the transatrial (and transpulmonary) approaches and restricted use of TAPs, have been widely adopted. Despite improvements in morbidity, follow-up duration for these techniques is probably too limited to demonstrate a survival benefit.

Our limited understanding of RV adaptation and the pathophysiology of RV heart failure hampers the ability to detect failure in early stages in clinical practice and to predict future decline of RV function. While a large proportion of adult ToF survivors require one or multiple PVRs in their lifetimes, selecting optimal candidates and optimal timing for PVR remains challenging. Increasing our understanding of RV failure seems key to answer these difficult questions. This might provide treatment options to attain optimal long-term health outcomes for patients with ToF.

\section{Abbreviations}

CCS, Canadian Cardiovascular Society; CHD, congenital heart disease; CMR, cardiovascular magnetic resonance; DA, ductus arteriosus; EDFF, end-diastolic forward flow; EDV, end-diastolic volume; EDVi, end-diastolic volume index; $\mathrm{EF}$, ejection fraction; ICD, implantable cardioverter defibrillator; LV, left ventricle; mBT, modified Blalock-Taussig; NT-proBNP, N-terminal pro brain natriuretic peptide; PA, pulmonary artery; PR, pulmonary regurgitation; PS, pulmonary stenosis; PVR, pulmonary valve replacement; RV, right ventricle; RVOT, right ventricular outflow tract; RVOTO, right ventricular outflow tract obstruction; SVT, supraventricular tachycardia; TAP, transannular patch; ToF, tetralogy of Fallot; TR, tricuspid regurgitation; VA, ventriculo-arterial; VT, ventricular tachycardia

\section{Grant information}

J.P.G. van der Ven and E. van den Bosch were supported by a research grant from the Dutch Heart Foundation (grant 2013T091 to W.A. Helbing and V.M. Christoffels).

The funders had no role in study design, data collection and analysis, decision to publish, or preparation of the manuscript.
1. van der Linde $D$, Konings EE, Slager MA, et al.: Birth prevalence of congenital heart disease worldwide: A systematic review and meta-analysis. J Am Coll Cardiol. 2011; 58(21): 2241-7.

PubMed Abstract | Publisher Full Text

2. F Neill CA, Clark EB: Tetralogy of Fallot. The first $\mathbf{3 0 0}$ years. Tex Heart Inst J. 1994; 21(4): 272-9.

PubMed Abstract | Free Full Text | F1000 Recommendation
3. Fallot ELA: Contribution à l'anatomie pathologique de la maladie bleue (cyanose cardiaque). Marseille Médical. 1888(25): 77-93.

4. F Englert JAR 3rd, Gupta T, Joury AU, et al.: Tetralogy of Fallot: Case-Based Update for the Treatment of Adult Congenital Patients. Curr Probl Cardiol. 2019; 44(2): 46-81.

PubMed Abstract | Publisher Full Text | F1000 Recommendation

5. Lillehei CW, Cohen M, Warden HE, et al.: Direct vision intracardiac surgical 
correction of the tetralogy of Fallot, pentalogy of Fallot, and pulmonary atresia defects; report of first ten cases. Ann Surg. 1955; 142(3): 418-42. PubMed Abstract | Publisher Full Text | Free Full Text

6. Kirklin JW, Blackstone $\mathrm{EH}$, Pacifico $\mathrm{AD}$, et al:: Risk factors for early and late failure after repair of tetralogy of Fallot, and their neutralization. Thorac cardiovasc Surg. 1984; 32(4): 208-14.

PubMed Abstract | Publisher Full Tex

7. Lillehei CW, Varco RL, Cohen M, et al:: The first open heart corrections of tetralogy of Fallot. A 26-31 year follow-up of 106 patients. Ann Surg. 1986; 204(4): 490-502.

PubMed Abstract | Publisher Full Text | Free Full Text

8. Wolf MD, Landtman B, Neill CA, et al:: TOTAL CORRECTION OF TETRALOGY OF FALLOT. I. FOLLOW-UP STUDY OF 104 CASES. Circulation. 1965; 31: 385-93. PubMed Abstract | Publisher Full Text

9. Azar H, Hardesty RL, Pontius RG, et al:: A review of total correction in $\mathbf{2 0 0}$ cases of tetralogy of Fallot. Arch Surg. 1969; 99(2): 281-5.

PubMed Abstract | Publisher Full Text

10. Goldman BS, Mustard WT, Trusler GS: Total correction of tetralogy of Fallot. Review of ten years' experience. Br Heart J. 1968; 30(4): 563-8. PubMed Abstract | Publisher Full Text | Free Full Text

11. Kirklin JW, Wallace RB, McGoon DC, et al.: Early and late results after intracardiac repair of Tetralogy of Fallot. 5-Year review of 337 patients. Ann Surg. 1965; 162(4): 578-89.

PubMed Abstract | Publisher Full Text | Free Full Text

12. Luijten LWG, van den Bosch E, Duppen N, et al:: Long-term outcomes of transatrial-transpulmonary repair of tetralogy of Fallot. European Journal of Cardio-Thoracic Surgery. 2015; 47(3): 527-34.

PubMed Abstract | Publisher Full Text

13. Carvalho JS, Shinebourne EA, Busst C, et al.: Exercise capacity after complete repair of tetralogy of Fallot: Deleterious effects of residual pulmonary regurgitation. Br Heart J. 1992; 67(6): 470-3.

PubMed Abstract | Publisher Full Text | Free Full Text

14. Gatzoulis MA, Till JA, Somerville J, et al:: Mechanoelectrical interaction in tetralogy of Fallot. QRS prolongation relates to right ventricular size and predicts malignant ventricular arrhythmias and sudden death. Circulation. 1995; 92(2): 231-7.

PubMed Abstract | Publisher Full Text

15. Khairy $\mathrm{P}$, Landzberg MJ, Gatzoulis MA, et al:: Value of programmed ventricula stimulation after tetralogy of fallot repair: A multicenter study. Circulation. 2004; 109(16): 1994-2000.

PubMed Abstract | Publisher Full Text

16. Bristow JD, Adrouny ZA, Porter GA, et al:: Hemodynamic studies after total correction of tetralogy of Fallot. Am J Cardiol. 1962; 9: 924-32. PubMed Abstract | Publisher Full Text

17. Ebert PA, Sabiston DC: Surgical management of the tetralogy of Fallot: Influence of a previous systemic-pulmonary anastomosis on the results of open correction. Ann Surg. 1967; 165(5): 806-13.

PubMed Abstract | Publisher Full Text | Free Full Text

18. Bushman GA: Tetralogy of Fallot. In: Dabbagh A, Conte AH, Lubin L, editors. Congenital Heart Disease in Pediatric and Adult Patients: Anesthetic and Perioperative Management. Cham: Springer International Publishing; 2017; 481-513. Publisher Full Text

19. Karl TR, Sano S, Pornviliwan S, et al.: Tetralogy of fallot: Favorable outcome of nonneonatal transatrial, transpulmonary repair. Ann Thorac Surg. 1992; 54(5): $903-7$. PubMed Abstract | Publisher Full Text

20. Parry AJ, McElhinney DB, Kung GC, et al:: Elective primary repair of acyanotic tetralogy of Fallot in early infancy: Overall outcome and impact on the pulmonary valve. J Am Coll Cardiol. 2000; 36(7): 2279-83. PubMed Abstract | Publisher Full Text

21. Stewart RD, Backer CL, Young L, et al.: Tetralogy of Fallot: Results of a pulmonary valve-sparing strategy. Ann Thorac Surg. 2005; 80(4): 1431-8; discussion 1438-9.

PubMed Abstract | Publisher Full Text

22. Fraser CD Jr, McKenzie ED, Cooley DA: Tetralogy of Fallot: Surgical management individualized to the patient. Ann Thorac Surg. 2001; 71(5): 1556-63. PubMed Abstract | Publisher Full Text

23. Mavroudis CD, Frost J, Mavroudis C: Pulmonary valve preservation and restoration strategies for repair of tetralogy of Fallot. Cardiol Young. 2014 24(6): 1088-94.

PubMed Abstract | Publisher Full Tex

24. Vida VL, Guariento A, Zucchetta F, et al:: Preservation of the Pulmonary Valve During Early Repair of Tetralogy of Fallot: Surgical Techniques. Semin Thorac Cardiovasc Surg Pediatr Card Surg Annu. 2016; 19(1): 75-81. PubMed Abstract | Publisher Full Text

25. Zavanella C, Miyamoto K, Subramanian S: RECONSTRUCTION OF THE RIGHT VENTRICULAR OUTFLOW TRACT WITH A POSTERIOR MONOCUSP VALVE. Cardiovasc Dis. 1978; 5(2): 128-31. PubMed Abstract | Free Full Text

26. Sasson L, Houri S, Raucher Sternfeld A, et al:: Right ventricular outflow tract strategies for repair of tetralogy of Fallot: Effect of monocusp valve reconstruction. Eur J Cardiothorac Surg. 2013; 43(4): 743-51. PubMed Abstract | Publisher Full Text
27. Mercer CW, West SC, Sharma MS, et al:: Polytetrafluoroethylene conduits versus homografts for right ventricular outflow tract reconstruction in infants and young children: An institutional experience. J Thorac Cardiovasc Surg. 2018; 155(5): 2082-2091.e1.

PubMed Abstract | Publisher Full Text

28. Choi $\mathrm{KH}$, Sung SC, Kim H, et al:: Late results of right ventricular outflow tract reconstruction with a bicuspid expanded polytetrafluoroethylene valved conduit. J Card Surg. 2018; 33(1): 36-40.

Publued Abstract Publisher Full Text

29. Alsoufi B, Williams WG, Hua Z, et al.: Surgical outcomes in the treatment of patients with tetralogy of Fallot and absent pulmonary valve. Eur $J$ Cardiothorac Surg. 2007; 31(3): 354-9; discussion 359.

PubMed Abstract | Publisher Full Text

30. Gupta U, Polimenakos AC, El-Zein C, et al:: Tetralogy of Fallot with atrioventricular septal defect: Surgical strategies for repair and midterm outcome of pulmonary valve-sparing approach. Pediatr Cardiol. 2013; 34(4): $861-71$

PubMed Abstract | Publisher Full Text

31. Kaza AK, Lim HG, DiBardino DJ, et al:: Long-term results of right ventricular outflow tract reconstruction in neonatal cardiac surgery: Options and outcomes. J Thorac Cardiovasc Surg. 2009; 138(4): 911-6.

PubMed Abstract | Publisher Full Text

32. Gerling C, Rukosujew A, Kehl HG, et al:: Do the age of patients with tetralogy of fallot at the time of surgery and the applied surgical technique influence the reoperation rate? a single-center experience. Herz. 2009; 34(2): 155-60. PubMed Abstract | Publisher Full Text

33. Nakashima K, Itatani K, Oka N, et al.: Pulmonary Annulus Growth After the Modified Blalock-Taussig Shunt in Tetralogy of Fallot. Ann Thorac Surg. 2014 98(3): 934-40.

PubMed Abstract | Publisher Full Text

34. Daliento L, Mapelli D, Russo G, et al:: Health related quality of life in adults with repaired tetralogy of Fallot: Psychosocial and cognitive outcomes. Heart 2005; 91(2): 213-8.

PubMed Abstract | Publisher Full Text | Free Full Text

35. Loomba RS, Buelow MW, Woods RK: Complete Repair of Tetralogy of Fallot in the Neonatal Versus Non-neonatal Period: A Meta-analysis. Pediatr Cardiol. 2017; 38(5): 893-901.

PubMed Abstract | Publisher Full Tex

36. Bakhtiary F, Dähnert I, Leontyev S, et al.: Outcome and Incidence of ReIntervention After Surgical Repair of Tetralogy of Fallot. J Card Surg. 2013; 28(1): 59-63.

PubMed Abstract | Publisher Full Text

37. Arenz $\mathrm{C}$, Laumeier $\mathrm{A}$, Lütter $\mathrm{S}$, et al: Is there any need for a shunt in the treatment of tetralogy of Fallot with one source of pulmonary blood flow? European Journal of Cardio-Thoracic Surgery. 2013; 44(4): 648-54. PubMed Abstract | Publisher Full Text

38. Kiran U, Aggarwal S, Choudhary A, et al:: The blalock and taussig shunt revisited. Ann Card Anaesth. 2017; 20(3): 323-330. PubMed Abstract | Publisher Full Text | Free Full Text

39. McKenzie ED, Khan MS, Samayoa AX, et al.: The Blalock-Taussig shunt revisited: A contemporary experience. J Am Coll Surg. 2013; 216(4): 699-704; discussion 704-6.

PubMed Abstract | Publisher Full Text

40. Lenko E, Kulyabin Y, Zubritskiy A, et al.: Influence of staged repair and primary repair on outcomes in patients with complete atrioventricular septal defect and tetralogy of Fallot: A systematic review and meta-analysis. Interact Cardiovasc Thorac Surg 2018; 26(1): 98-105.

PubMed Abstract | Publisher Full Text

41. Mimic B, Brown KL, Oswal N, et al:: Neither age at repair nor previous palliation affects outcome in tetralogy of Fallot repair. Eur J Cardiothorac Surg. 2014; 45(1): 92-8. discussion 99. PubMed Abstract | Publisher Full Text

42. Alwi M: Stenting the ductus arteriosus: Case selection, technique and possible complications. Ann Pediatr Cardiol. 2008; 1(1): 38-45. PubMed Abstract | Publisher Full Text | Free Full Text

43. F Bentham JR, Zava NK, Harrison WJ, et al:: Duct Stenting Versus Modified Blalock-Taussig Shunt in Neonates With Duct-Dependent Pulmonary Blood Flow: Associations With Clinical Outcomes in a Multicenter National Study. Circulation. 2018; 137(6): 581-8 PubMed Abstract | Publisher Full Text | F1000 Recommendation

44. F Glatz AC, Petit CJ, Goldstein BH, et al:: Comparison Between Patent Ductus Arteriosus Stent and Modified Blalock-Taussig Shunt as Palliation for Infants With Ductal-Dependent Pulmonary Blood Flow: Insights From the Congenita Catheterization Research Collaborative. Circulation. 2018; 137(6): 589-601. PubMed Abstract | Publisher Full Text | F1000 Recommendation

45. Godart F, Rey C, Prat A, et al:: Early and late results and the effects on pulmonary arteries of balloon dilatation of the right ventricular outflow tract in tetralogy of Fallot. Eur Heart J. 1998; 19(4): 595-600.

PubMed Abstract | Publisher Full Text

46. Remadevi KS, Vaidyanathan B, Francis E, et al:: Balloon pulmonary valvotomy as interim palliation for symptomatic young infants with tetralogy of Fallot. Ann Pediatr Cardiol. 2008; 1(1): 2-7. PubMed Abstract | Publisher Full Text | Free Full Text 
47. Laudito A, Bandisode VM, Lucas JF, et al.: Right Ventricular Outflow Tract Stent as a Bridge to Surgery in a Premature Infant with Tetralogy of Fallot. Ann Thorac Surg. 2006; 81(2): 744-6.

PubMed Abstract | Publisher Full Text

48. Dohlen G, Chaturvedi RR, Benson LN, et al:: Stenting of the right ventricular outflow tract in the symptomatic infant with tetralogy of Fallot. Heart. 2009; 95(2): 142-7.

PubMed Abstract | Publisher Full Text

49. F Quandt D, Ramchandani B, Penford G, et al:: Right ventricular outflow tract stent versus BT shunt palliation in Tetralogy of Fallot. Heart. 2017; 102(24): $1985-1991$. PubMed Abstract | Publisher Full Text | F1000 Recommendation

50. F Quandt D, Ramchandani B, Stickley J, et al.: Stenting of the Right Ventricular Outflow Tract Promotes Better Pulmonary Arterial Growth Compared With Modified Blalock-Taussig Shunt Palliation in Tetralogy of Fallot-Type Lesions. JACC Cardiovasc Interv. 2017; 10(17): 1774-84.

PubMed Abstract | Publisher Full Text | F1000 Recommendation

51. Sandoval JP, Chaturvedi RR, Benson L, et al:: Right Ventricular Outflow Tract Stenting in Tetralogy of Fallot Infants With Risk Factors for Early Primary Repair. Circ Cardiovasc Interv. 2016; 9(12): pii: e003979.

PubMed Abstract | Publisher Full Text

52. F Wilder TJ, van Arsdell GS, Benson L, et al.: Young infants with severe tetralogy of Fallot: Early primary surgery versus transcatheter palliation. J Thorac Cardiovasc Surg. 2017; 154(5): 1692-1700.e2.

PubMed Abstract | Publisher Full Text | F1000 Recommendation

53. Kim H, Sung SC, Kim SH, et al.: Early and late outcomes of total repair of tetralogy of Fallot: risk factors for late right ventricular dilatation. Interact Cardiovasc Thorac Surg. 2013; 17(6): 956-62.

PubMed Abstract | Publisher Full Text | Free Full Text

54. Ylitalo $\mathrm{P}$, Nieminen $\mathrm{H}$, Pitkänen OM, et al:: Need of transannular patch in tetralogy of Fallot surgery carries a higher risk of reoperation but has no impact on late survival: results of Fallot repair in Finland. Eur $J$ Cardiothorac Surg. 2015; 48(1): 91-7. Surg. 2015; 48(1): $91-7$.
PubMed Abstract | Publisher Full Text

55. Park CS, Lee JR, Lim HG, et al:: The long-term result of total repair for tetralogy of Fallot. Eur J Cardiothorac Surg. 2010; 38(3): 311-7.

PubMed Abstract | Publisher Full Text

56. Boening A, Scheewe J, Paulsen J, et al:: Tetralogy of Fallot: influence of surgical technique on survival and reoperation rate. Thorac Cardiovasc Surg. 2001; 49(9): 355-60.

PubMed Abstract | Publisher Full Text

57. Chiu SN, Wang JK, Chen HC, et al.: Long-term survival and unnatural deaths of patients with repaired tetralogy of Fallot in an Asian cohort. Circ Cardiovas Qual Outcomes. 2012; 5(1): 120-5.

PubMed Abstract | Publisher Full Text

58. Hamada H, Terai M, Jibiki T, et al.: Influence of early repair of tetralogy of fallot without an outflow patch on late arrhythmias and sudden death: a 27-year follow-up study following a uniform surgical approach. Cardiol Young. 2002; 12(4): 345-51.

PubMed Abstract | Publisher Full Text

59. Hashemzadeh K, Hashemzadeh S: Early and late results of total correction of tetralogy of Fallot. Acta Med Iran. 2010; 48(2): 117-22. PubMed Abstract

60. Hokanson JS, Moller JH: Significance of early transient complete heart block as a predictor of sudden death late after operative correction of tetralogy of Fallot. Am J Cardiol. 2001; 87(11): 1271-7.

PubMed Abstract | Publisher Full Text

61. Lee JR, Kim JS, Lim HG, et al:: Complete repair of tetralogy of Fallot in infancy. Interact Cardiovasc Thorac Surg. 2004; 3(3): 470-4.

PubMed Abstract | Publisher Full Text

62. Nollert G, Fischlein T, Bouterwek $\mathrm{S}$, et al.: Long-term survival in patients with repair of tetralogy of Fallot: 36-year follow-up of $\mathbf{4 9 0}$ survivors of the first year after surgical repair. J Am Coll Cardiol. 1997; 30(5): 1374-83. PubMed Abstract | Publisher Full Text

63. F Cuypers JA, Menting ME, Konings EE, et al.: Unnatural history of tetralogy of Fallot: prospective follow-up of $\mathbf{4 0}$ years after surgical correction. Circulation. 2014; 130(22): 1944-53

PubMed Abstract | Publisher Full Text | F1000 Recommendation

64. d'Udekem Y, Galati JC, Rolley GJ, et al.: Low risk of pulmonary valve implantation after a policy of transatrial repair of tetralogy of Fallot delayed beyond the neonatal period: the Melbourne experience over 25 years. $J A m$ Coll Cardiol. 2014; 63(6): 563-8.

PubMed Abstract | Publisher Full Text

65. Hickey EJ, Veldtman G, Bradley TJ, et al.: Late risk of outcomes for adults with repaired tetralogy of Fallot from an inception cohort spanning four decades. Eur J Cardiothorac Surg. 2009; 35(1): 156-64; discussion 164. PubMed Abstract | Publisher Full Text

66. Sarris GE, Comas JV, Tobota Z, et al:: Results of reparative surgery for tetralogy of Fallot: data from the European Association for Cardio-Thoracic Surgery Congenital Database. Eur J Cardiothorac Surg. 2012; 42(5): 766-74; discussion 774.

PubMed Abstract | Publisher Full Text
67. Jacobs JP, Mayer JE Jr, Pasquali SK, et al.: The Society of Thoracic Surgeons Congenital Heart Surgery Database: 2018 Update on Outcomes and Quality. Ann Thorac Surg. 2018; 105(3): 680-9. PubMed Abstract | Publisher Full Text

68. Jacobs JP, Mayer JE Jr, Mavroudis C, et al.: The Society of Thoracic Surgeons Congenital Heart Surgery Database: 2017 Update on Outcomes and Quality. Ann Thorac Surg. 2017; 103(3): 699-709.

PubMed Abstract | Publisher Full Text

69. Kirklin JW, Blackstone EH, Colvin EV, et al.: Early primary correction of tetralogy of Fallot. Ann Thorac Surg. 1988; 45(3): 231-3. PubMed Abstract | Publisher Full Text

70. Pigula FA, Khalil PN, Mayer JE, et al:: Repair of tetralogy of Fallot in neonates and young infants. Circulation. 1999; 100(19 Suppl): II157-61. PubMed Abstract

71. Saygi M, Ergul $\mathrm{Y}$, Tola HT, et al:: Factors affecting perioperative mortality in tetralogy of Fallot. Pediatr Int. 2015; 57(5): 832-9.

PubMed Abstract | Publisher Full Text

72. Jonas RA: Early primary repair of tetralogy of Fallot. Semin Thorac Cardiovasc Surg Pediatr Card Surg Annu. 2009; 12: 39-47. PubMed Abstract | Publisher Full Text

73. Mouws EMJP, de Groot NMS, van de Woestijne PC, et al.: Tetralogy of Fallot in the Current Era. Semin Thorac Cardiovasc Surg. 2018; pii: S1043-0679(18)30314-9. PubMed Abstract | Publisher Full Text

74. Cedars A, Benjamin L, Vyhmeister R, et al.: Contemporary Hospitalization Rate Among Adults With Complex Congenital Heart Disease. World J Pediatr Congenit Heart Surg. 2016; 7(3): 334-43. PubMed Abstract | Publisher Full Text

75. Warnes CA, Williams RG, Bashore TM, et al:: ACC/AHA 2008 guidelines for the management of adults with congenital heart disease: a report of the American College of Cardiology/American Heart Association Task Force on Practice Guidelines (Writing Committee to Develop Guidelines on the Management of Adults With Congenital Heart Disease). Developed in Collaboration With the American Society of Echocardiography, Heart Rhythm Society, International Society for Adult Congenital Heart Disease, Society for Cardiovascular Angiography and Interventions, and Society of Thoracic Surgeons. J Am Coll Cardiol. 2008; 52(23): e143-e263.

PubMed Abstract | Publisher Full Text

76. Silversides CK, Kiess M, Beauchesne L, et al:: Canadian Cardiovascular Society 2009 Consensus Conference on the management of adults with congenital heart disease: outflow tract obstruction, coarctation of the aorta, tetralogy of Fallot, Ebstein anomaly and Marfan's syndrome. Can J Cardiol. 2010; 26(3): e80-e97.

PubMed Abstract | Publisher Full Text | Free Full Text

77. Baumgartner H, Bonhoeffer P, De Groot NM, et al.: ESC Guidelines for the management of grown-up congenital heart disease (new version 2010). Eur Heart J. 2010; 31(23): 2915-57.

PubMed Abstract | Publisher Full Text

78. Valente AM, Gauvreau K, Assenza GE, et al:: Contemporary predictors of death and sustained ventricular tachycardia in patients with repaired tetralogy of Fallot enrolled in the INDICATOR cohort. Heart. 2014; 100(3): 247-53. PubMed Abstract | Publisher Full Text | Free Full Text

79. Bass JL: Percutaneous balloon dilation angioplasty of pulmonary artery branch stenosis. Cardiovasc Intervent Radiol. 1986; 9(5-6): 299-302. PubMed Abstract

80. Bové T, François $\mathrm{K}$, van de Kerckhove $\mathrm{K}$, et al.: Assessment of a right-ventricular infundibulum-sparing approach in transatrial-transpulmonary repair of tetralogy of Fallot. Eur J Cardiothorac Surg. 2012; 41(1): 126-33. PubMed Abstract | Publisher Full Text | Free Full Text

81. F Padalino MA, Cavalli G, Albanese SB, et al.: Long-term outcomes following transatrial versus transventricular repair on right ventricular function in tetralogy of Fallot. J Card Surg. 2017; 32(11): 712-20. PubMed Abstract | Publisher Full Text | F1000 Recommendation

82. Hoashi T, Kagisaki K, Meng Y, et al.: Long-term outcomes after definitive repair for tetralogy of Fallot with preservation of the pulmonary valve annulus. J Thorac Cardiovasc Surg. 2014; 148(3): 802-8; discussion 808-9. PubMed Abstract | Publisher Full Text

83. Sfyridis PG, Kirvassilis GV, Papagiannis JK, et al.: Preservation of right ventricular structure and function following transatrial-transpulmonary repai of tetralogy of Fallot. Eur J Cardiothorac Surg. 2013; 43(2): 336-42. PubMed Abstract | Publisher Full Text

84. Mercer-Rosa L, Yang W, Kutty S, et al:: Quantifying pulmonary regurgitation and right ventricular function in surgically repaired tetralogy of Fallot: a comparative analysis of echocardiography and magnetic resonance imaging. Circ Cardiovasc Imaging. 2012; 5(5): 637-43.

PubMed Abstract | Publisher Full Text | Free Full Text

85. Redington AN: Physiopathology of right ventricular failure. Semin Thorac Cardiovasc Surg Pediatr Card Surg Annu. 2006; 9(1): 3-10. PubMed Abstract | Publisher Full Text

86. Bouzas B, Kilner PJ, Gatzoulis MA: Pulmonary regurgitation: not a benign lesion. Eur Heart J. 2005; 26(5): 433-9. PubMed Abstract | Publisher Full Text

87. Park SJ, On YK, Kim JS, et al: Relation of fragmented QRS complex to right ventricular fibrosis detected by late gadolinium enhancement cardiac 
magnetic resonance in adults with repaired tetralogy of fallot. Am J Cardiol. 2012; 109(1): 110-5.

PubMed Abstract | Publisher Full Text

88. Frigiola A, Hughes M, Turner M, et al:: Physiological and phenotypic characteristics of late survivors of tetralogy of fallot repair who are free from pulmonary valve replacement. Circulation. 2013; 128(17): 1861-8.

PubMed Abstract | Publisher Full Text

89. van der Hulst AE, Hylkema MG, Vliegen $\mathrm{HW}$, et al:: Mild residual pulmonary stenosis in tetralogy of fallot reduces risk of pulmonary valve replacement. Ann Thorac Surg. 2012; 94(6): 2077-82. PubMed Abstract | Publisher Full Text

90. O'Byrne ML, Glatz AC, Mercer-Rosa $\mathrm{L}$, et al:: Trends in pulmonary valve replacement in children and adults with tetralogy of fallot. Am J Cardiol. 2015; 115(1): 118-24.

PubMed Abstract | Publisher Full Text | Free Full Text

91. Geva T, Gauvreau K, Powell AJ, et al:: Randomized trial of pulmonary valve replacement with and without right ventricular remodeling surgery. Circulation. 2010; 122(11 Suppl): S201-S208. PubMed Abstract | Publisher Full Text | Free Full Text

92. F Ferraz Cavalcanti PE, Sá MP, Santos CA, et al:: Pulmonary valve replacement after operative repair of tetralogy of Fallot: meta-analysis and meta-regression of 3,118 patients from 48 studies. J Am Coll Cardiol. 2013; 62(23): 2227-43.

PubMed Abstract | Publisher Full Text | F1000 Recommendation

93. F Bhagra CJ, Hickey EJ, van de Bruaene A, et al:: Pulmonary Valve Procedures Late After Repair of Tetralogy of Fallot: Current Perspectives and Contemporary Approaches to Management. Can J Cardiol. 2017; 33(9): 1138-49. PubMed Abstract | Publisher Full Text | F1000 Recommendation

94. F Bokma JP, Geva T, Sleeper LA, et al:: A propensity score-adjusted analysis of clinical outcomes after pulmonary valve replacement in tetralogy of Fallot. Heart. 2018; 104(9): 738-44.

PubMed Abstract | Publisher Full Text | F1000 Recommendation

95. $\quad F$ Meijer FMM, Kies $P$, Jongbloed MRM, et al.: Excellent durability of homografts in pulmonary position analysed in a predefined adult group with tetralogy of Fallot. Interact Cardiovasc Thorac Surg. 2019; 28(2): 279-83. PubMed Abstract | Publisher Full Text | F1000 Recommendation

96. van de Woestijne PC, Mokhles MM, de Jong PL, et al:: Right ventricular outflow tract reconstruction with an allograft conduit in patients after tetralogy of Fallot correction: long-term follow-up. Ann Thorac Surg. 2011; 92(1): 161-6. PubMed Abstract | Publisher Full Text

97. Motta SE, Lintas V, Fioretta ES, et al:: Off-the-shelf tissue engineered heart valves for in situ regeneration: current state, challenges and future directions. Expert Rev Med Devices. 2017; 15(1): 35-45.

PubMed Abstract | Publisher Full Text

98. Dijkman PE, Fioretta ES, Frese L, et al.: Heart Valve Replacements with Regenerative Capacity. Transfus Med Hemother. 2016; 43(4): 282-90. PubMed Abstract | Publisher Full Text | Free Full Text

99. Jones MI, Qureshi SA: Recent advances in transcatheter management of pulmonary regurgitation after surgical repair of tetralogy of Fallot [version 1; peer review: 3 approved]. F1000Res. 2018; 7: pii: F1000 Faculty Rev-679. PubMed Abstract | Publisher Full Text | Free Full Text

100. F Chatterjee A, Bajaj NS, McMahon WS, et al.: Transcatheter Pulmonary Valve Implantation: A Comprehensive Systematic Review and Meta-Analyses of Observational Studies. J Am Heart Assoc. 2017; 6(8): pii: e006432. PubMed Abstract | Publisher Full Text | Free Full Text | F1000 Recommendation

101. McElhinney DB: Reflection and Rationalization: Making Sense of the Literature on Endocarditis After Transcatheter Pulmonary Valve Replacement. Circ Cardiovasc Interv. 2017; 10(2): pii: e004983. PubMed Abstract | Publisher Full Text

102. F Nordmeyer J, Ewert P, Gewillig M, et al.: Acute and midterm outcomes of the post-approval MELODY Registry: a multicentre registry of transcatheter pulmonary valve implantation. Eur Heart J. 2019; pii: ehz201. pulmonary valve implantation. Eur Heart J. 2019; pii: ehz201.
PubMed Abstract | Publisher Full Text | F1000 Recommendation

103. Robichaud B, Hill G, Cohen S, et al.: Bioprosthetic pulmonary valve endocarditis: Incidence, risk factors, and clinical outcomes. Congenit Heart Dis. 2018; 13(5): 734-9.

PubMed Abstract | Publisher Full Text

104. Müller J, Engelhardt A, Fratz S, et al.: Improved exercise performance and quality of life after percutaneous pulmonary valve implantation. Int $\mathrm{J}$ Cardiol. 2014; 173(3): 388-92

PubMed Abstract | Publisher Full Text

105. Batra AS, McElhinney DB, Wang W, et al:: Cardiopulmonary exercise function among patients undergoing transcatheter pulmonary valve implantation in the US Melody valve investigational trial. Am Heart J. 2012; 163(2): 280-7. PubMed Abstract | Publisher Full Text

106. F Bokma JP, Winter MM, Vehmeijer JT, et al:: QRS fragmentation is superior to QRS duration in predicting mortality in adults with tetralogy of Fallot. Heart. 2017; 103(9): 666-71.

PubMed Abstract | Publisher Full Text | F1000 Recommendation

107. Khairy P, Aboulhosn J, Gurvitz MZ, et al.: Arrhythmia burden in adults with surgically repaired tetralogy of Fallot: a multi-institutional study. Circulation 2010; 122(9): 868-75.

PubMed Abstract | Publisher Full Text

108. Gatzoulis MA, Balaji S, Webber SA, et al:: Risk factors for arrhythmia and sudden cardiac death late after repair of tetralogy of Fallot: a multicentre study. Lancet. 2000; 356(9234): 975-81.

PubMed Abstract | Publisher Full Tex

109. F Dennis M, Moore B, Kotchetkova I, et al:: Adults with repaired tetralogy: low mortality but high morbidity up to middle age. Open Heart. 2017; 4(1): e000564. PubMed Abstract | Publisher Full Text | Free Full Text | F1000 Recommendation

110. Sherwin ED, Triedman JK, Walsh EP: Update on interventional electrophysiology in congenital heart disease: evolving solutions for complex hearts. Circ Arrhythm Electrophysiol. 2013; 6(5): 1032-40. PubMed Abstract | Publisher Full Tex

111. F Laredo M, Frank R, Waintraub X, et al:: Ten-year outcomes of monomorphic ventricular tachycardia catheter ablation in repaired tetralogy of Fallot. Arch Cardiovasc Dis. 2017; 110(5): 292-302.

PubMed Abstract | Publisher Full Text | F1000 Recommendation

112. Harrison DA, Siu SC, Hussain F, et al:: Sustained atrial arrhythmias in adults late after repair of tetralogy of fallot. Am J Cardiol. 2001; 87(5): 584-8. PubMed Abstract | Publisher Full Text

113. F Orczykowski M, Borowiec K, Biernacka E, et al:: Ablation of atrial tachyarrhythmias late after surgical correction of tetralogy of Fallot: long-term follow-up. Kardiol Pol. 2018; 76(7): 1097-105. PubMed Abstract | Publisher Full Text | F1000 Recommendation

114. F Refaat MM, Ballout J, Mansour M: Ablation of Atrial Fibrillation in Patients with Congenital Heart Disease. Arrhythm Electrophysiol Rev. 2017; 6(4): 191-4. PubMed Abstract | Publisher Full Text | Free Full Text | F1000 Recommendation

115. F Ezzat VA, Ryan MJ, O'Leary J, et al:: Radiofrequency ablation of atrial tachyarrhythmias in adults with tetralogy of Fallot - predictors of success and outcome. Cardiol Young. 2017; 27(2): 284-93.

PubMed Abstract | Publisher Full Text | F1000 Recommendation

116. Cruz C, Pinho T, Ribeiro V, et al:: Aortic dilatation after tetralogy of Fallot repair: A ghost from the past or a problem in the future? Rev Port Cardiol. 2018; 37(7): 549-57.

PubMed Abstract | Publisher Full Text

117. Niwa K, Siu SC, Webb GD, et al:: Progressive aortic root dilatation in adults late after repair of tetralogy of Fallot. Circulation. 2002; 106(11): 1374-8. PubMed Abstract | Publisher Full Text

118. Cruz C, Pinho T, Madureira AJ, et al.: Is it important to assess the ascending aorta after tetralogy of Fallot repair? Rev Port Cardiol. 2018; 37(9): 773-9. PubMed Abstract | Publisher Full Text

119. Frischhertz BP, Shamszad P, Pedroza C, et al.: Thoracic aortic dissection and rupture in conotruncal cardiac defects: A population-based study. Int $J$ Cardiol. 2015; 184: 521-7. PubMed Abstract | Publisher Full Text

120. F Takei K, Murakami T, Takeda A: Implication of Aortic Root Dilation and Stiffening in Patients with Tetralogy of Fallot. Pediatr Cardiol. 2018; 39(7): 1462-7. PubMed Abstract | Publisher Full Text | F1000 Recommendation

121. F Bossers GPL, Hagdorn QAJ, Ploegstra MJ, et al:: Volume load-induced right ventricular dysfunction in animal models: insights in a translational gap in congenital heart disease. Eur J Heart Fail. 2018; 20(4): 808-12. PubMed Abstract | Publisher Full Text | F1000 Recommendation

122. Kuehne $\mathrm{T}$, Saeed M, Gleason $\mathrm{K}$, et al.: Effects of pulmonary insufficiency on biventricular function in the developing heart of growing swine. Circulation. 2003; 108(16): 2007-13.

PubMed Abstract | Publisher Full Text

123. Friedberg MK, Redington AN: Right versus left ventricular failure: differences, similarities, and interactions. Circulation. 2014; 129(9): 1033-44. PubMed Abstract | Publisher Full Text

124. Reddy S, Bernstein D: The vulnerable right ventricle. Curr Opin Pediatr. 2015 27(5): 563-8.

PubMed Abstract | Publisher Full Text

125. Reddy S, Bernstein D: Molecular Mechanisms of Right Ventricular Failure. Circulation. 2015; 132(18): 1734-42. PubMed Abstract | Publisher Full Text | Free Full Text

126. $\mathrm{F}$ Benoist $\mathrm{D}$, Dubes $\mathrm{V}$, Roubertie $\mathrm{F}$, et al.: Proarrhythmic remodelling of the right ventricle in a porcine model of repaired tetralogy of Fallot. Heart. 2017; 103(5): 347-54.

PubMed Abstract | Publisher Full Text | Free Full Text | F1000 Recommendation

127. F Dubes V, Benoist D, Roubertie F, et al:: Arrhythmogenic Remodeling of the Left Ventricle in a Porcine Model of Repaired Tetralogy of Fallot. Circ Arrhythm Electrophysiol. 2018; 11(10): e006059.

PubMed Abstract | Publisher Full Text | Free Full Text | F1000 Recommendation

128. Reddy S, Zhao M, Hu DQ, et al:: Physiologic and molecular characterization of a murine model of right ventricular volume overload. Am J Physiol Heart Circ Physiol. 2013; 304(10): H1314-27.

PubMed Abstract | Publisher Full Text | Free Full Text

129. Bartelds B, Borgdorff MA, Smit-van Oosten A, et al.: Differential responses of the 
right ventricle to abnormal loading conditions in mice: pressure vs. volume load. Eur J Heart Fail. 2011; 13(12): 1275-82.

PubMed Abstract | Publisher Full Text

130. Rebergen SA, Chin JG, Ottenkamp J, et al.: Pulmonary regurgitation in the late postoperative follow-up of tetralogy of Fallot. Volumetric quantitation by nuclear magnetic resonance velocity mapping. Circulation. 1993; 88(5 Pt 1): 2257-66.

PubMed Abstract | Publisher Full Text

131. F Knauth AL, Gauvreau K, Powell AJ, et al.: Ventricular size and function assessed by cardiac MRI predict major adverse clinical outcomes late after tetralogy of Fallot repair. Heart. 2008; 94(2): 211-6.

PubMed Abstract | Publisher Full Text | F1000 Recommendation

132. Davlouros PA, Kilner PJ, Hornung TS, et al.: Right ventricular function in adults with repaired tetralogy of Fallot assessed with cardiovascular magnetic resonance imaging: detrimental role of right ventricular outflow aneurysms or akinesia and adverse right-to-left ventricular interaction. J Am Coll Cardiol. 2002; 40(11): 2044-52.

PubMed Abstract | Publisher Full Text

133. O'Meagher S, Munoz PA, Alison JA, et al.: Exercise capacity and stroke volume are preserved late after tetralogy repair, despite severe right ventricular dilatation. Heart. 2012; 98(21): 1595-9. PubMed Abstract | Publisher Full Text

134. Pettersen E, Helle-Valle T, Edvardsen $\mathrm{T}$, et al.: Contraction pattern of the systemic right ventricle shift from longitudinal to circumferential shortening and absent global ventricular torsion. J Am Coll Cardiol. 2007; 49(25): 2450-6. PubMed Abstract | Publisher Full Text

135. Orwat S, Diller GP, Kempny A, et al:: Myocardial deformation parameters predict outcome in patients with repaired tetralogy of Fallot. Heart. 2016; 102(3): 209-15.

PubMed Abstract | Publisher Full Text

136. Diller GP, Kempny A, Liodakis E, et al:: Left ventricular longitudinal function predicts life-threatening ventricular arrhythmia and death in adults with repaired tetralogy of fallot. Circulation. 2012; 125(20): 2440-6. PubMed Abstract | Publisher Full Tex

137. Vogel M, Sponring J, Cullen S, et al.: Regional wall motion and abnormalities of electrical depolarization and repolarization in patients after surgical repair of tetralogy of Fallot. Circulation. 2001; 103(12): 1669-73. PubMed Abstract | Publisher Full Text

138. Menting ME, van den Bosch AE, McGhie JS, et al.: Assessment of ventricular function in adults with repaired Tetralogy of Fallot using myocardial deformation imaging. Eur Heart J Cardiovasc Imaging. 2015; 16(12): 1347-57. PubMed Abstract | Publisher Full Text

139. Jing L, Wehner GJ, Suever JD, et al.: Left and right ventricular dyssynchrony and strains from cardiovascular magnetic resonance feature tracking do not predict deterioration of ventricular function in patients with repaired tetralogy of Fallot. J Cardiovasc Magn Reson. 2016; 18(1): 49. PubMed Abstract | Publisher Full Text | Free Full Text

140. F Kalaitzidis $\mathrm{P}$, Orwat S, Kempny A, et al.: Biventricular dyssynchrony on cardiac magnetic resonance imaging and its correlation with myocardial deformation, ventricular function and objective exercise capacity in patients with repaired tetralogy of Fallot. Int J Cardiol. 2018; 264: 53-7. PubMed Abstract | Publisher Full Text | F1000 Recommendation

141. F Yim D, Hui W, Larios G, et al:: Quantification of Right Ventricula Electromechanical Dyssynchrony in Relation to Right Ventricular Function and Clinical Outcomes in Children with Repaired Tetralogy of Fallot. J Am Soc Echocardiogr. 2018; 31(7): 822-30.

PubMed Abstract | Publisher Full Text | F1000 Recommendation

142. F Koyak Z, de Groot JR, Krimly A, et al.: Cardiac resynchronization therapy in adults with congenital heart disease. Europace. 2018; 20(2): 315-22. PubMed Abstract | Publisher Full Text | F1000 Recommendation

143. F Mercer-Rosa L, Fogel MA, Paridon SM, et al.: Revisiting the End-Diastolic Forward Flow (Restrictive Physiology) in Tetralogy of Fallot: An Exercise, Echocardiographic, and Magnetic Resonance Study. JACC Cardiovasc Imaging. 2018; 11(10): 1547-8

PubMed Abstract | Publisher Full Text | F1000 Recommendation

144. Gatzoulis MA, Clark AL, Cullen S, et al.: Right ventricular diastolic function 15 to 35 years after repair of tetralogy of Fallot. Restrictive physiology predicts superior exercise performance. Circulation. 1995; 91(6): 1775-81. PubMed Abstract | Publisher Full Text

145. Helbing WA, Niezen RA, Le Cessie S, et al:: Right ventricular diastolic function in children with pulmonary regurgitation after repair of tetralogy of Fallot: volumetric evaluation by magnetic resonance velocity mapping. J Am Coll Cardiol. 1996; 28(7): 1827-35.

PubMed Abstract | Publisher Full Tex

146. Kutty S, Valente AM, White MT, et al:: Usefulness of Pulmonary Arterial EndDiastolic Forward Flow Late After Tetralogy of Fallot Repair to Predict a "Restrictive" Right Ventricle. Am J Cardiol. 2018; 121(11): 1380-6. PubMed Abstract | Publisher Full Text

147. Luijnenburg SE, Peters RE, van der Geest RJ, et al:: Abnormal right atrial and right ventricular diastolic function relate to impaired clinical condition in patients operated for tetralogy of Fallot. Int J Cardiol. 2013; 167(3): 833-9. PubMed Abstract | Publisher Full Text
148. F Kutty S, Shang Q, Joseph N, et al:: Abnormal right atrial performance in repaired tetralogy of Fallot: A CMR feature tracking analysis. Int $J$ Cardiol. 2017: 248: 136-42.

PubMed Abstract | Publisher Full Text | F1000 Recommendation

149. Latus H, Binder W, Kerst G, et al:: Right ventricular-pulmonary arterial coupling in patients after repair of tetralogy of Fallot. J Thorac Cardiovasc Surg. 2013; 146(6): 1366-72

PubMed Abstract | Publisher Full Text

150. Tretter JT, Redington AN: The Forgotten Ventricle? The Left Ventricle in RightSided Congenital Heart Disease. Circ Cardiovasc Imaging. 2018; 11(3): e007410. PubMed Abstract | Publisher Full Text

151. Geva T, Sandweiss BM, Gauvreau K, et al:: Factors associated with impaired clinical status in long-term survivors of tetralogy of Fallot repair evaluated by magnetic resonance imaging. J Am Coll Cardiol. 2004; 43(6): 1068-74. PubMed Abstract | Publisher Full Text

152. Lurz P, Puranik R, Nordmeyer J, et al.: Improvement in left ventricular filling properties after relief of right ventricle to pulmonary artery conduit obstruction: contribution of septal motion and interventricular mechanical delay. Eur Heart J. 2009; 30(18): 2266-74. PubMed Abstract | Publisher Full Text

153. Ghai $A$, Silversides $C$, Harris $L$, et al.: Left ventricular dysfunction is a risk factor for sudden cardiac death in adults late after repair of tetralogy of Fallot. J Am Coll Cardiol. 2002; 40(9): 1675-80. PubMed Abstract | Publisher Full Text

154. Assenza GE, Graham DA, Landzberg MJ, et al:: MELD-XI score and cardiac mortality or transplantation in patients after Fontan surgery. Heart. 2013; 99(7): $491-6$.

PubMed Abstract | Publisher Full Text

155. Roche SL, Redington AN: Right ventricle: wrong targets? Another blow for pharmacotherapy in congenital heart diseases. Circulation. 2013; 127(3): 314-6. PubMed Abstract | Publisher Full Text

156. Babu-Narayan SV, Uebing A, Davlouros PA, et al.: Randomised trial of ramipril in repaired tetralogy of Fallot and pulmonary regurgitation: the APPROPRIATE study (Ace inhibitors for Potential PRevention Of the deleterious effects of Pulmonary Regurgitation In Adults with repaired TEtralogy of Fallot). Int $J$ Cardiol. 2012; 154(3): 299-305.

PubMed Abstract | Publisher Full Tex

157. Cao JY, Lee SY, Phan K, et al:: Renin-angiotensin-aldosterone inhibition improves right ventricular function: a meta-analysis. Heart Asia. 2018; 10(1): e010999.

PubMed Abstract | Publisher Full Text | Free Full Text

158. Bokma JP, Winter MM, van Dijk AP, et al.: Effect of Losartan on Right Ventricular Dysfunction: Results From the Double-Blind, Randomized REDEFINE Trial (Right Ventricular Dysfunction in Tetralogy of Fallot: Inhibition of the ReninAngiotensin-Aldosterone System) in Adults With Repaired Tetralogy of Fallot. Circulation. 2018; 137(14): 1463-71. PubMed Abstract | Publisher Full Text

159. Norozi K, Bahlmann J, Raab B, et al.: A prospective, randomized, double-blind, placebo controlled trial of beta-blockade in patients who have undergone surgical correction of tetralogy of Fallot. Cardiol Young. 2007; 17(4): 372-9. PubMed Abstract | Publisher Full Text

160. F Sarikouch S, Boethig D, Beerbaum P: Gender-specific algorithms recommended for patients with congenital heart defects: review of the literature. Thorac cardiovasc Surg. 2013; 61(1): 79-84. PubMed Abstract | Publisher Full Text | F1000 Recommendation

161. F Heng EL, Gatzoulis MA, Uebing A, et al:: Immediate and Midterm Cardiac Remodeling After Surgical Pulmonary Valve Replacement in Adults With Repaired Tetralogy of Fallot: A Prospective Cardiovascular Magnetic Resonance and Clinical Study. Circulation. 2017; 136(18): 1703-13. PubMed Abstract | Publisher Full Text | Free Full Text | F1000 Recommendation

162. Robbers-Visser D, Boersma E, Helbing WA: Normal biventricular function, volumes, and mass in children aged $\mathbf{8}$ to 17 years. J Magn Reson Imaging. 2009; 29(3): 552-9. PubMed Abstract | Publisher Full Text

163. Sarikouch S, Peters B, Gutberlet M, et al:: Sex-specific pediatric percentiles for ventricular size and mass as reference values for cardiac MRI: assessment by steady-state free-precession and phase-contrast MRI flow. Circ Cardiovasc Imaging. 2010; 3(1): 65-76. PubMed Abstract | Publisher Full Text

164. Buechel EV, Kaiser T, Jackson C, et al.: Normal right- and left ventricular volumes and myocardial mass in children measured by steady state free precession cardiovascular magnetic resonance. J Cardiovasc Magn Reson 2009; 11: 19. PubMed Abstract | Publisher Full Text | Free Full Text

165. van der Ven JPG, Sadighy Z, Valsangiacomo Buechel ER, et al.: Multicentre reference values for cardiac magnetic resonance imaging derived ventricular size and function for children aged 0-18 years. Eur Heart J Cardiovasc Imaging. 2019; pii: jez164. PubMed Abstract | Publisher Full Text

166. El-Harasis MA, Connolly HM, Miranda WR, et al.: Progressive right ventricular enlargement due to pulmonary regurgitation: Clinical characteristics of a "lowrisk" group. Am Heart J. 2018; 201: 136-40.

PubMed Abstract | Publisher Full Text 
167. Wald RM, Valente AM, Gauvreau K, et al:: Cardiac magnetic resonance markers of progressive RV dilation and dysfunction after tetralogy of Fallot repair. Heart. 2015; 101(21): 1724-30.

PubMed Abstract | Publisher Full Text

168. F Rutz T, Ghandour F, Meierhofer C, et al.: Evolution of right ventricular size over time after tetralogy of Fallot repair: a longitudinal cardiac magnetic resonance study. Eur Heart J Cardiovasc Imaging. 2017; 18(3): 364-70. PubMed Abstract | Publisher Full Text | F1000 Recommendation

169. Luijnenburg SE, Helbing WA, Moelker A, et al: 5-year serial follow-up of clinical condition and ventricular function in patients after repair of tetralogy of Fallot. Int J Cardiol. 2013; 169(6): 439-44. PubMed Abstract | Publisher Full Text

170. Shin YR, Jung JW, Kim NK, et al.: Factors associated with progression of right ventricular enlargement and dysfunction after repair of tetralogy of Fallot based on serial cardiac magnetic resonance imaging. Eur J Cardiothorac Surg. 2016; 50(3): 464-9.

PubMed Abstract | Publisher Full Text
171. Wijesekera VA, Raju R, Precious B, et al.: Sequential Right and Left Ventricular Assessment in Posttetralogy of Fallot Patients with Significant Pulmonary Regurgitation. Congenit Heart Dis. 2016; 11(6): 606-14.

PubMed Abstract | Publisher Full Text

172. F Bhat M, Mercer-Rosa L, Fogel MA, et al.: Longitudinal changes in adolescents with TOF: implications for care. Eur Heart J Cardiovasc Imaging.

2017; 18(3): 356-63.
PubMed Abstract | Publisher Full Text | Free Full Text | F1000 Recommendation

173. Grothoff M, Hoffmann J, Lehmkuhl L, et al:: Time course of right ventricular functional parameters after surgical correction of tetralogy of Fallot determined by cardiac magnetic resonance. Clin Res Cardiol. 2011; 100(4): 343-50.

PubMed Abstract | Publisher Full Text

174. Baggen VJM, Venema E, Živná R, et al:: Development and validation of a risk prediction model in patients with adult congenital heart disease. Int J Cardiol. 2019; 276: 87-92.

PubMed Abstract | Publisher Full Text 


\section{Open Peer Review}

\section{Current Peer Review Status:}

\section{Editorial Note on the Review Process}

Faculty Reviews are review articles written by the prestigious Members of Faculty Opinions. The articles are commissioned and peer reviewed before publication to ensure that the final, published version is comprehensive and accessible. The reviewers who approved the final version are listed with their names and affiliations.

\section{The reviewers who approved this article are:}

\section{Version 1}

\section{Luc Mertens}

The Labatt Family Heart Centre, The Hospital for Sick Children, University of Toronto, Toronto, ON, Canada

Competing Interests: No competing interests were disclosed.

\section{Gianfranco Butera}

Department of Paediatric and Adult Congenital Heart Disease, Evelina London Children's Hospital, Guy's and St Thomas' NHS Foundation Trust, London, UK

Competing Interests: No competing interests were disclosed.

The benefits of publishing with F1000Research:

- Your article is published within days, with no editorial bias

- You can publish traditional articles, null/negative results, case reports, data notes and more

- The peer review process is transparent and collaborative

- Your article is indexed in PubMed after passing peer review

- Dedicated customer support at every stage

For pre-submission enquiries, contact research@f1000.com 